\title{
6 \\ The Racing of Ainu Hearts: Our Wish for One Salmon River
}

\section{Shizue Ukaji (translated by Miku Maeda)}

My name is Shizue Ukaji. ${ }^{1}$ I come from Saitama prefecture, and am 84 years old. I wish to rest peacefully in heaven as an Ainu, but I cannot put my mind at rest, because the situation surrounding Ainu people never gets better. I even think that it is worse than when I was born.

We had once traded across the northern sea, hunted deer in the meadows and hills of Ainu Mosir (the land of the Ainu), picked edible wild plants and captured salmon swimming upstream in the rivers. But in the Edo period (1603-1868), the shogunate system made its presence felt on Ainu Mosir and the Matsumae Domain was set up in its southern part, the Oshima Peninsula. Our ancestors were forced to stop trading over the seas and the area in which they could conduct business was limited. The Ainu economy was seized exclusively for the support of the Matsumae Domain.

A modern state was established in the Meiji period (1868-1912) but what they did in the first place was to rename the land of Yezo as 'Hokkaidō' and govern it as a territory of Japan. Only 1 per cent of Hokkaidō was Wajinchi (the land of Japanese) and rest was Ainu Mosir. In spite of that, the Japanese Government took the land of Yezo by force, asserted

1 Shizue Ukaji, 'The racing of Ainu hearts: Our wish for one salmon river', Speech prepared for the International Conference on Policy towards Indigenous Peoples: Lessons to be learned, Sapporo, 2-4 December, 2017. 
a principle of terra nullius, and failed to seek the consent of the Ainu. Who can be ignorant of such injustice? Not even one piece of land has yet been given back to Ainu people. Injustice continues.

A scene from my childhood is printed in my memory. When my father got home from work in the mountains, the old Ainu men and women of our neighbourhood would gather at our house. My father treated his Utari, his friends, to liquor and food. Such feasts lasted for days. Men and ladies danced, and I felt their energy was powerful enough to break the floors. It was the same as young people these days being excited with rock music. I saw and found that they were full of joy in being Ainu.

I do not see such scenes anymore. We have lost our Indigenous power. Surely, our culture, such as songs, dances, embroidery and woodcarving are still with us thanks to our ancestors. Many Utari are learning embroidery, woodcarving and Ainu language. I also invented a technique of embroidery called kofüe, which creates pictures from cloth that depict Ainu ancient myths. I have had exhibitions throughout Japan and I have received prizes too. But there is no peace in my mind. My Ainu heart is not racing.

They danced by the fireside all night long, but now I see that the tide of hearty joy has gone from us. I feel loneliness in this situation where we cannot have our way of life and our culture, even if we can learn our culture itself. Ainu culture, such as embroidery, woodcarving, songs and dances, was once enmeshed in our life; it could not be separated from it. Our hearts are not racing for this lifeless culture.

Chiri Yukie, the author of Ainu Shinyōshü wrote the following:

Getting over deep snow in the winter forest, in the face of a fit of shivering, hunting bears over mountain ranges / a green wave with cool breeze played over it at the summer ocean, with songs of dear white seagulls, catching fish on a leaf-like boat all day / under the peaceful sunlight in the flowerblossomed spring, a life with birds singing, eternally picking butterburs and wormwoods / an autumn day, a blowing windstorm over pampas grass with ears, no bonfire for salmon fishery, echoing sound of deer for friends in valley, a dream under the round moon (1978: 3). 
It might sound extremely idealistic. This kind of life, integrated with nature, was already deep in the past even at the time of my parents. But my father still hunted in the mountains and captured fish, and harvested tangled seaweed from the sea. All of my family was engaged in collecting seaweed and we still had an Ainu life with nature.

Chiri Yukie also wrote the following:

We have been defeated in the keen competition, but someday, some strong people will appear out of us and we will rise up to compete with the world, as it moves on and on (1978: 4).

It has been approximately a century since she wrote Ainu Shinyōsh $\bar{u}$ in 1922. But I still wonder whether 'some strong people' have really appeared amongst us. Perhaps they have appeared once in a while, and then vanished straight away. We have been labelled as Japanese, discarded and sunken deep into their society. We are still struggling to rise to the surface.

Young Ainu Utari are working hard-some of them even have global horizons. However, the structure of Japanese society is just the way it was. Even after a century, we are still not able to see a world in which the injustice toward Ainu people has been rectified, making life as peaceful for Ainu people, as it is for the Japanese.

The Japanese Government eventually recognised the Ainu as the Indigenous people of Japan in 2008. They promised to create a comprehensive Indigenous policy toward Ainu people. But their current policy does not include Indigenous rights. The base of such rights includes rights related to land, resources, occupation and independence. The policy includes none of them. I find it hard to believe that the government takes our issues seriously.

I will not come close to being one of Chiri Yukie's 'strong people'. I am just one of the grass-roots Ainu. I am full of the feeling of wishing to pass a better situation on to young Utari in my remaining lifetime.

My idea is quite simple. I want the government to give us back one river in Hokkaidō. It is very clear that salmon fishing was our main occupation. Asircepnomi, the ceremony for welcoming new salmon, is still conducted throughout Hokkaidō every year. But, our right to fish salmon was taken away in the Meiji period. There is no choice but to join a Japanese fishermen's union if Ainu people want to fish for salmon now. 
But if just one river of Hokkaidō was given back, we could engage in salmon fishing for and by Ainu people in an Ainu river.

It will not be easy, for sure. Questions such as who manages the river and how, how profits will be distributed, how the river and its resources will be shared and, apart from such economic issues, how we can do all this in an Ainu spirit need to be considered.

But we can start from the process of ukoitaku (negotiation, discussion), and address these issues one by one between Ainu. It is difficult for us now to sit down and discuss something. Mutual trust is crucial for communication - to speak your mind, to listen to others, and revise your opinion if necessary. Sadly, we have lost the sense of Utari along with the loss of our community, kotan. One salmon river is the first step to retrieving our lost circuit of communication.

We can learn by trial and error. If an attempt goes successfully, it can become a model, and can generate the next one. In this way, we can practise Indigenous Ainu rights step by step. We have to do it by ourselves, with difficulty, not by unilateral agreement. That is the only way to get back the power of Ainu. However, it needs an enormous effort to claim back one river of Hokkaidō since the Japanese Government has adopted the stance of not accepting Indigenous rights. We must explain the fairness of our rights not only to the government but also to the public, by going back to Ainu history. We have been the people who were made smaller-now we need a bigger voice. I would like to ask your help, my Indigenous brothers and sisters in the world. I would like to ask your help to make our voice into the voice of the world. One river can become a breakthrough.

Spring brings me a memory, though we are still in winter. It is a memory of chitatap made of the big-scaled redfin fish. Chitatap can be translated into English as 'to mince'. Big-scaled redfins used to come to irrigation channels with spawn inside their bodies in the warm spring. We caught them and minced them, and ate them with grated horseradish. It was so tasty. That is Ainu food culture, eating Mother Nature's flavour fresh, with as little processing as possible. Ainu life like that existed until half a century ago.

But schools of big-scaled redfins vanished when people started spraying pesticide on their rice fields. This disappearance of these fish from the irrigation channels due to the forces of modernisation seems to me to overlap with the disappearance of the Ainu's traditional occupation. 
We Ainu people must engage in salmon fishing in our own river. Ainu hearts must race in the body of Ainu men. Mine also races as well, just thinking about it. Claiming one of our salmon rivers-it sounds like a small claim compared to having our Indigenous rights acknowledged. But for me, it is the big first step towards inverting national policies towards Ainu people.

I believe that the spirit of the Ainu will be gradually regenerated along with the revival of our life. This is the important point. We have the great legacy of Ainu Shinyō, the Ainu epics of the gods. They are full of Ainu thought and spirit. But now, they are still confined to the world of paper. They have to be brought back as living thought and spirit to our daily life. Ainu culture can finally thrive with that, and my heart will race again.

We Ainu wish for one salmon river. To make this small wish come true, I would like to ask your help, our Indigenous brothers and sisters from around the world. Iyairaikere (thank you).

\section{References}

Ukaji, Shizue. 2017. 'The racing of Ainu hearts: Our wish for one salmon river'. Speech prepared for the International Conference on Policy towards Indigenous Peoples: Lessons to be Learned, Sapporo, 2-4 December.

Yukie, Chiri. 1978. Ainu Shin'yōshū [Ainu Gods' Tales]. Iwanami Bunko, Tokyo: Iwanami Shoten. 
This text is taken from Indigenous Efflorescence: Beyond Revitalisation in Sapmi and Ainu Mosir, edited by Gerald Roche, Hiroshi Maruyama and Åsa Virdi Kroik, published 2018 by ANU Press, The Australian National University, Canberra, Australia.

doi.org/10.22459/IE.2018.06 